\title{
Shared Identity, Family Influence, and the Transgenerational Intentions in Family Firms
}

\author{
Raj V. Mahto ${ }^{1}$, Jiun-Shiu Chen ${ }^{2}$, William C. McDowell ${ }^{3, *(1)}$ and Saurabh Ahluwalia ${ }^{1}$ (D) \\ 1 Anderson School of Management, The University of New Mexico, Albuquerque, NM 87131, USA; \\ rmahto@unm.edu (R.V.M.); sahluwalia@unm.edu (S.A.) \\ 2 College of Business, McNeese State University, Lake Charles, LA 70605, USA; jschen@mcneese.edu \\ 3 Foster College of Business, Bradley University, Peoria, IL 61625, USA \\ * Correspondence: wmcdowell@bradley.edu
}

Received: 30 December 2018; Accepted: 11 February 2019; Published: 21 February 2019

\begin{abstract}
A family's transgenerational intention (TI) to pass ownership of the firm to the next generation of family members is the defining characteristic of a family. TI reflects a family's intention to engage in succession planning, which is the primary predictor for succession success. In this study, we draw on psychological ownership theory to develop and test a model of a family's TI. In the model, we argue that family influence impacts TI through shared identity. We also argue that a family firm CEO's relationship to the family (by blood vs. marriage vs. hire) moderates the relationship between shared identity and TI. We tested our hypotheses and the model on a sample of North American family firms and found support for most hypotheses.
\end{abstract}

Keywords: family influence; shared identity; transgenerational intentions; CEO family ties

\section{Introduction}

Cross-generational sustainability [1] or the intention to pass the business on to the next generation [2,3] distinguishes family firms from non-family firms [4]. In defining family firms, scholars have proposed that, besides significant financial ownership of and involvement in the firm, the family's transgenerational intention (TI) towards the family entity is a key defining characteristic [5-7]. A family's TI reflects, not only its commitment to the family firm, but also the firm's financial and socioemotional importance to the family [8]. Further, TI indicates the family's desire to preserve the entity for future generations for the perpetuation of the family dynasty and family values. When TI is absent, the motivation for the family's involvement in a firm is primarily financial, with the firm unlikely to fulfill the family's need of intimacy, reciprocity, and commitment to other family members. Thus, a family firm without TI may resemble a non-family firm. The controlling family's concern for non-economic benefits, socioemotional wealth, in non-family firms may be absent or negligible [9]. Empirical findings in the family firm literature has supported a strong and positive correlation between TI and a family's socioemotional wealth [7], which encompasses a variety of non-economic and emotionally meaningful objectives [9].

In the family firm literature, succession has been a dominant theme with scholars investigating various issues associated with it [10]. This is because succession represents a critical transition event, where family firms face a considerable survival risk. Unfortunately, a considerable number of family firms fail to navigate the succession process and ultimately perish [11,12]. Among the surviving firms, succession induces a considerable change in the firm's behavior and performance [13]. Thus, considerable attention in the family firm literature have has been devoted to understanding the succession process. Some of the succession issues investigated are succession planning [14], commitment to succession [15], family vs. non-family succession [16], relationship between incumbent 
and successor [17], and successor characteristics [4]. In the literature, succession planning has emerged as the key predictor for a successful transition [14]. As intentions precede an actual behavior or action [18], family's TI is the key antecedent for them to engage in succession planning in a family firm.

More recently, research on TI in family firms has grown, but the literature on factors influencing the development of TI is surprisingly underdeveloped [19]. Specifically, the research on factors contributing to the development of TI in the family controlling the family firm is missing. This gap in the literature impacts family firm scholars' efforts toward a unique family firm focused theoretical framework. Thus, our goal in this paper is to contribute towards a better understanding of the antecedents to a family's TI. We draw on psychological ownership theory [20] to develop a model of a family's TI. In the model, we develop theoretical arguments for the family influence as the antecedent of TI. We propose that a family's shared identity with the business (hereafter referred to as shared identity) mediates the influence of the family on TI. Finally, we argue that the family firm CEO type, based on their relationship in controlling the family, moderates the relationship in the model. We use three CEO types in this paper: (1) CEO related to the family by blood or adoption, (2) CEO related to the family through marriage, and (3) CEO not related to the family. Finally, we tested our proposed model on a sample of North American family firms.

Our paper makes many significant contributions to the family firm literature. First, our study extends Williams, Zorn, Crook, and Combs' [19] work on TI from founder (individual level) to family (group level). However, our study employs a richer measure of TI and utilizes psychological ownership theory. Second, our study introduces the notion of shared identity, which we define as the degree of overlap between the family identity and business identity, this being an antecedent of TI. While prior literature has indirectly argued that shared identity is linked with TI, studies on the predictors of shared identity in family firms are lacking. Further, we established shared identity as a mediator for the relationship between the family influence and TI. Third, our study contributes to the debate on family CEOs vs non-family CEOs by further sub-dividing the family CEOs into family CEOs related to the family by blood/adoption and family CEOs related to the family by marriage. We believe this distinction is important to investigate as views about in-laws vary significantly across the world [21]. Finally, our study establishes that the relationship between shared identity and TI is contingent on the type of CEO in family firms, which, to our knowledge, remains unexplored.

In the next section, we briefly describe the shared identity construct. We develop our model using theoretical arguments in the section labeled theory development. In the method section, we describe our sample followed by a description of the study measures in the variables section. In the analysis section, we explain the statistical procedures and tools that we used for testing the prosed model and study hypotheses. Our present study findings are in the results section and we conclude the paper with a discussion of the study's findings.

\section{Shared Identity}

Individual behavior is a manifestation of an individual's identity, and defines who they are. According to social identity theory, a person's identity is strongly shaped by the collective identity of a group to which they belong [22,23]. Organizations have their own unique constructed identity that affects its members' behavior even in the absence of a direct interaction with the group [24]. The formation of organizational identity is a complex process steeped in ambiguity and subject to multiple influences [25]. Organizational identity is a reflection of an organization that may be conceived of as an entity or a social actor with a distinct personality, manner, and style [26].

Organizational identity is expressed through specific commitments that affect its self-image and perception by other organizations as well as the community or society as a whole [27]. Commitments that facilitate expressions of a particular organizational identity have been described as "identity claims" [28]. Organizational members may share a particular organizational identity if they define themselves using the same attributes as the organization; such a cognitive association between an organization and its members is achieved through the process of identification [29]. Identification 
occurs as a result of the adoption of a certain self-definition as a member of a social group. Social identity theory is applicable to the family firm in which family members may form close associations as they become emotionally engaged and mutually dependent over time [11]. Family firms are composed of two different groups, family and firm, which most likely have separate identities. However, as the family may often be involved in managing the firm besides ownership of the firm, there is a high probability of overlap between family identity and business identity. In some family firms, especially first-generation family firms, family identity and business identity are aligned so closely that the distinction between family identity and business identity no longer exists. However, in some family firms, especially firms that have endured multiple generational succession, there may be clear distinction between family identity and business identity. The overlap between family and business identities may vary in other family firms. To account for the level of overlap between family and business identities in the study, we introduced the construct of shared identity, which we defined above as "the degree of overlap between family identity and business identities".

\section{Theory Development}

Scholars in social psychology have suggested that an individual's valued possessions shape their identity [30], which ultimately impacts their attitude and behavior [31]. The integration of valued possessions to an individual's identity may be so strong that the loss of possessions may represent a threat to the individual. Pearce, Kostova, and Dirks [20] used the phenomenon to develop psychology ownership theory, which argues for an individual with psychological ownership towards a specific target, such as their employing firm, will develop a strong attachment (e.g., commitment) and extra responsibility (e.g., protecting) for the target. However, individuals develop psychological ownership of the target only if they: (a) Control the target; (b) have deep knowledge of the target; and (c) have significant investment in the target. In utilizing psychological ownership theory, Mahto, Ahluwalia, and Khanin [4] suggest that heirs who 'earn' the family firm, through their investment of labor and financial resources over time, are more likely to develop psychological ownership of the firm and remain committed to it. In this paper, we draw on the psychological ownership theory to develop our arguments.

\subsection{Family Influence over the Family Business and Family's Business Identity}

Families need to maintain control of family firms to accumulate social capital and maximize its socioemotional wealth. Without exercising control of the family firm, the realization of family's non-economic goals would be cast into doubt [32]. The absence of control over the family firm will also hinder the development of psychological ownership in a family towards the firm (4). The way the governing coalition maintains its power and authority over the family firm is often described as the family influence over the family business [32-34]. However, family influence has been approached in the literature from different perspectives. Some authors viewed it as ranging from low (with at least one family member involved in firm management) to high (multiple generations retaining ownership and employment in the business) [35], but this involvement is important for the sustainability of the family firm [36].

In contrast, the family influence on power, experience, and culture (F-PEC) theory suggests that family influence represents a rather complex phenomenon that should not be reduced to one factor, such as the representation of the family on the top management team [37]. Instead, the F-PEC identifies the three main dimensions of family involvement that may serve as the conduits of family influence over the family firm: Power, experience, and culture. Other scholars have defined family involvement as structured around family ownership and used a battery of diverse measures, such as equity ownership of the founding family and family members' presence on the board of directors, to capture such effects [33].

In addition, researchers have conceptualized family influence as encompassing ownership, participation in management, and involvement of numerous generations of the family [32]. From an 
empirical perspective, family involvement may be assessed as the percentage and duration of family ownership [7]. In our view, family influence encompasses not merely family ownership, but also the relative importance of a family's wealth tied up in the family firm compared to the total family wealth. A family may own the entire family business and yet not be deeply involved in its governance if the share of the family's wealth invested in the business is insignificant. This will hinder strong integration between the family and firm identities, which, according to the psychological ownership theory [20], may prevent the development of psychological ownership of a firm in the family.

Family influence could also be related to various mechanisms of control, which is one of three key conditions for the development of psychological ownership [20] over the family firm employed by the family. One of these mechanisms is regularly held family meetings. Such meetings may allow the family to influence those of its members that manage the family firm. Additionally, family members and non-family members, shareholders of the family firm, could also exert influence over the management of the family firm during shareholder meetings. Finally, family members that are part of the top management team could be regarded as yet another mechanism that may secure family influence. These could help the family develop an intimate knowledge of the firm, which, according to the psychological ownership theory, will enhance integration between the family and firm identities. This will result in a higher overlap between the family identity and business identity, which results in stronger shared identity.

Given that the family may exercise rather comprehensive control over the family firm, by utilizing psychological ownership theory one could argue that the higher the family control over the family firm is, the greater the integration between the family and business identities, which may enhance socioemotional wealth associated with the firm. This is because once the family becomes actively involved in the management of the family firm and can influence it in many different ways, the identity of the family business becomes entwined with the family's identity. Hence, as a family exercises its influence over the family firm and becomes increasingly involved in its operations, its shared identity is enhanced. Therefore:

Hypothesis 1. In family firms, the family influence over the firm will positively influence shared identity.

\subsection{Transgenerational Intentions (TI) and Shared Identity}

As a family develops a higher sense of shared identity, its desire to keep the family firm in the family becomes stronger. The family develops a strong sense of attachment towards the firm and assumes extra responsibility towards it [4], such that the goals related to the shared identity can become part of a family's socioemotional wealth and acquire emotional significance $[38,39]$.

Recent research has shown that organizations and individuals may form a positive, work-related identity for several reasons [40]. Virtuosity represents the first reason organizations may be interested in forming a positive identity. Certain conduct, such as giving back to the community, may be perceived by people as being inherently good. Therefore, a family may be interested in developing a virtuous business identity because of its deeply held ethical convictions. The second reason is evaluative. Assessing one's behavior, individual or organizational, enhances self-esteem. Respectively, a family with an excellent business reputation may feel good about its conduct and seek to continue with its ingrained virtuous orientation in conducting its business.

The additional mechanisms for boosting positive identity are adaptive, developmental, and structural [40]. Developmental mechanisms push individuals and organizations toward advancement, inspiring them to make their self-image more ideal. Adaptive mechanisms facilitate adjustment to the environment. Finally, the structural mechanisms of identity formation can be regarded as balanced and complementary. Balanced mechanisms allow the achievement of greater harmony between inclusiveness, the desire to be part of a larger community, and differentiation, the desire to distinguish oneself from others and achieve greater success. The complementary components of 
structural mechanisms allow the building of connections between different aspects of identity, such as social and economic, and effectively fuse those aspects together [40].

According to the psychological ownership theory, strong integration between family identity and business identity may result in a family failing to distinguish between the firm and the family. In such a condition, any threat to the firm, either its well-being or survival, will be treated as a threat to the family itself. The formation of a positive work-related identity, rooted in social identity theory, also addresses how shared identity may impact the TI. Shared identity will positively affect a family's TI whenever the virtuous, evaluative, and progressive mechanisms of identity formation are activated. Specifically, shared identity may be reinforced for the family when there is a strong community pressure to constantly remind the family about the interdependence between the family reputation and business image. Finally, shared identity can force the family and the business to help each other perpetuate the common shared values and to defend against common threats. As shared identity binds the family and the firm in a relationship, where the boundaries of each group are significantly blurred, the threat and risks to one group is equally threating to the other. Thus, we propose:

Hypothesis 2. In family firms, shared identity will positively influence the TI.

Family influence in the firm allows a family to exercise control over the firm while enjoying economic and non-economic (socioemotional) benefits associated with the control. Furthermore, control over a target allows the development of psychological ownership towards the target, which results in commitment and responsibility towards the target. In family firms, commitment has been shown to enhance TI [21]. This information, when considered in conjunction with arguments for the hypotheses, $\mathrm{H} 1$ and $\mathrm{H} 2$, leads us to predict:

Hypothesis 3. In family firms, shared identity will mediate the relationship between family influence and the TI.

\subsection{CEO Type: Relatedness by Blood, through Hire, and through Marriage}

Firm CEOs have significant influence over setting the strategic direction and behavioral outcome of their firm [41]. They also influence firm employees' and stakeholders' identification (with the firm) through their daily representation, communications, and interactions with them [42]. When the CEO belongs to the family (i.e., is a blood relative), the familial norms of intimacy, reciprocity, and commitment towards family-members, representing the desire to perpetuate family continuity, enables the family to have a stronger psychological ownership of the firm [20,43]. The higher feeling of psychological ownership towards the family entity may lead to a stronger identification with the firm. Conversely, when a non-family member becomes the CEO, the family firm may begin to resemble a non-family business as new governance structures could separate the family from direct, daily, and informal relationship-based control of the business. This could potentially affect the ability of family members to identify with the firm.

Furthermore, non-family CEOs, who are neither family nor married into the family, may reflect the owners' desire to professionalize the family firm by prioritizing firm perpetuation over family perpetuation. It may also reflect the family's desire to weaken the link between the family and the firm, and further question the family's TI. The selection of a non-family CEO may weaken the familial norms and the associated feeling of psychological ownership of the family firm [4]. Hence, the CEO's status as a family vs. non-family member may affect the relationship between the family's business identity and the TI. CEOs that are family members related by blood to the family could be more ingrained in family life, compared to non-family CEOs, and thus enjoy more opportunities to influence other family members as well as be influenced by them. At the same time, nonfamily CEOs' support for the family's business identity could also be seen as the position of the family rather than merely the CEO's. 
Hence, both family and non-family CEOs could strengthen the link between the family's business identity and the TI.

Family firm researchers have examined whether being a family member helps CEOs improve firms' performances [36]. Some studies have shown that CEOs that are family members are more effective than non-family CEOs apparently due to their enhanced social ties with the family and greater embeddedness within the family firm [44] as well as thanks to early socialization into the family culture [45].

Conversely, other studies have discovered that CEOs that belong to the family may be prone to taking on excessive risks in their strategy [46] as well as taking on too much debt, thus increasing the cost of debt financing [47]. At the same time, non-family CEOs, with a financial stake in increasing firms' performances, are more likely to engage in decisions and actions without considering or prioritizing family members' concerns [48]. While a family CEO may increase financial risk for the family, a non-family CEO may increase socioemotional risk for the family. Thus, the debate of family versus non-family CEOs in family firms remains inconclusive. However, family firm studies on CEOs' relationship to the family has further separated into 'related to family by blood' or 'related to family by marriage' $[21,49,50]$. For example, a study comparing the effectiveness of CEOs in family firms found CEOs related to the family by marriage enjoyed an advantage over the other two CEO types [50]. This is because views about the role of in-laws in family firms vary across countries [51]. In some cultures (e.g., India), in-laws are strongly integrated in family firms, while in other businesses, transactions with in-laws are strictly off-limits [21]. Thus, we believe it is important to further sub-divide family CEOs into CEOs related to the family through blood/adoption and CEOs related to the family through marriage.

Unlike family and non-family CEOs, who ascend to the top position by virtue of their family embeddedness, the strength of their social network, insider connections, and/or management talent, CEOs related to the family through marriage may be perceived by family members quite negatively. Such CEOs may neither share the sense of family identity nor have the benefit of extensive experience of unrelated CEOs. Hence, CEOs related to the family through marriage could be seen as lacking the managerial talent of CEOs related to the family through hiring and the family embeddedness of CEOs related to the family by blood.

When CEOs related to the family through marriage rise to the top of the family firm and hence acquire tremendous power over family members, this could create doubt that the family has been successful in building its business identity. Respectively, family members may harbor doubts regarding the family's ability to retain control of the firm in the future. Therefore, CEOs related to the family through marriage could be viewed by family members with suspicion. Family members could be dissatisfied with such CEOs' lack of familiarity with the family culture and getting ahead of blood-related family members. Family members could also hold against CEOs related through marriage their lack of outside experience and reputation. As a result, CEO relatedness by marriage could negatively moderate the relationship between the family's business identity and the TCI. Therefore:

Hypothesis 4. In family firms, the CEO type will moderate the relationship between shared identity and the TI.

\section{Method}

We used a sample of North American family firms to test the proposed model and the associated hypotheses. The family business centers at two distinct universities in the United States of America conducted the survey in partnership with a financial company serving family firms to collect the data. For the survey, the data collectors randomly selected firms from a list of family firms maintained by a commercial entity, Dun \& Bradstreet. Additional firm constrains for inclusion in the survey were: (1) Ten or more employees; (2) two million or more dollars in annual revenues; (3) 10 years or older in age; and (4) identify itself as a family firm. 
The sample had observations for 3033 family firms, but the final study sample had only 2154 firms after we deleted firms with missing entries. In the final sample, the distribution of family firms on CEO types was: (1) 1891-CEOs related to family by blood/adoption (RB), (2) 152-CEOs related to family by marriage (RM), and (3) 111—non-family CEOs (NF). As we had a fairly large sample size, we decided to undertake a more constrained and rigorous statistical approach to test our model. In this approach, we tested the proposed model in three-phased structural equation modeling. For the first phase, we further sub-divided the sample containing the family firms with CEOs related to the family by blood/adoption ( 945 family firms in each sub-sample). In the first phase (calibration phase) of the data analysis, we used one of the sub-samples with 945 firms to assess the fit of the proposed model, presented in Figure 1, but without moderating the variable CEO types. In the calibration phase, we tested multiple competitive models, including models with relationships opposite to those we theoretically predicted (e.g., family business identity $\rightarrow$ family meetings), to revise the model and to rule out alternative explanations. In phase two, we validated the resulting revised model from phase one by reassessing the second sub-sample of 945 family firms. Finally, in phase three, we assessed the moderating effects of $\mathrm{CEO}$ types using measurement invariance.

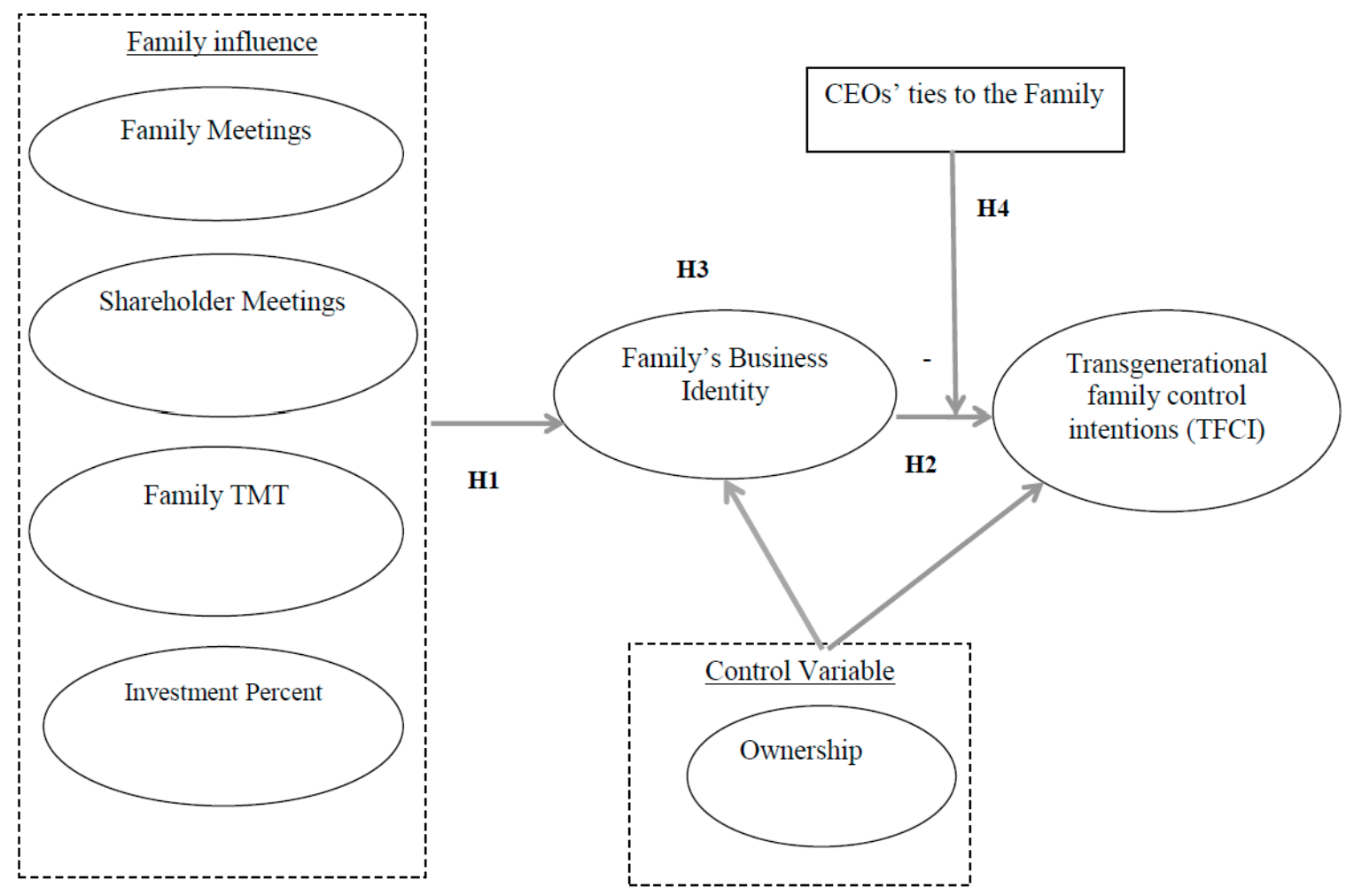

Figure 1. The Theoretical Model.

\section{Variables}

Family Influence: We measured family influence in the study using: The frequency of family meetings (family meetings), the frequency of shareholder meetings (shareholder meetings), the number of family members on the TMT (family TMT), and relative family investment in the business (investment percent). For family meetings and shareholder meetings, family firm respondents indicated their preference on four available options: $0,1-2,3-4$, or 5 , or greater than 5 . For family TMT, family firm respondents indicated the absolute number of family members serving in the firm's top management. Finally, investment percent assessed the family's net worth associated with the family entity and ranged from less than $20 \%$ (indicated as 1 ) to more than $80 \%$ (indicated as 5). 
Shared Identity: We measured this variable using a single item scale that asked respondents to indicate the overlap between family identity and business identity in the community. A 5-point Likert-type scale was used to capture the answers ranging from $1=$ Not at All to $5=$ Very Much So.

Transgenerational Intention(s) (TI): In the literature, some family firm scholars have utilized a single item [19,32]. In contrast, other scholars have used two-item scales to measure it [7]. For this study, we used a two-item scale to operationalize this construct. The two items on the scale were: (1) How strongly does the senior generation want the business to stay in the family? and (2) How strongly is the next generation committed to long-term business ownership? As the two items were highly correlated (Cronbach's $\alpha>0.80$ ), we created a single measure by averaging the two items.

Control Variables: As the relative distribution of family wealth among family members may influence their perception of control over the family entity, we controlled for family ownership (number of adult owners in family) in the study.

\section{Analyses}

\section{Analysis}

We used structural equation modeling using software LISREL [52] for the assessment of the hypotheses and the proposed model. To obtain unbiased results, we specified measurement loadings and error variances during the analysis [53]. In our model, measure loadings were fixed at $(\sqrt{\alpha}) \sigma$ (with $\alpha$ equal scale reliability and $\sigma$ equal scale standard deviation) and error variances were $(1-\alpha) \sigma^{2}$ (with $\alpha$ equal scale reliability and $\sigma^{2}$ equal scale variance) [52,54]. The probability of measurement error in a single-item scale is higher. Thus, we accounted for the measurement errors in single-item scales by fixing their reliability $(\alpha)$ at 0.85 [55]. Finally, we used a variety of fit indices (e.g., statistics, AGFI-adjusted goodness of fit index, GFI-goodness of fit index, NFI-normed fit index, CFI-comparative fit index, RMSEA-root-mean-square-error of approximation, and RMR-standardized root-mean-square-residuals) [56-58]) to assess the fit of the proposed model with the data.

\section{Results}

In Table 1, we report the correlation among the study variables along with the mean and standard deviation. In the table, the four family influence variables (shareholder meetings, family meetings, family TMT, and investment percent) are positively correlated with shared identity. The correlation between shared identity and TI was consistent with our prediction. In general, the correlations among the study variables do not rise to a level evidencing multicollinearity.

Table 1. Correlation among study variables for the first data set.

\begin{tabular}{|c|c|c|c|c|c|c|c|c|c|c|c|c|}
\hline Variables & 1 & & 2 & & 3 & & 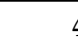 & & 5 & & 6 & 7 \\
\hline Ownership & 1 & & & & & & & & & & & \\
\hline Shareholder Meeting & 0.08 & ** & 1 & & & & & & & & & \\
\hline Family Meeting & -0.05 & * & 0.26 & $* *$ & 1 & & & & & & & \\
\hline Shared Identity & 0.05 & * & 0.08 & $* *$ & 0.18 & $* *$ & 1 & & & & & \\
\hline Family TMT & 0.18 & $* *$ & 0.14 & $* *$ & 0.22 & $* *$ & 0.17 & $* *$ & 1 & & & \\
\hline Investment Percent & 0.00 & & -0.03 & & -0.02 & & 0.07 & $* *$ & 0.01 & & 1 & \\
\hline $\mathrm{TI}$ & 0.09 & $* *$ & 0.07 & $* *$ & 0.14 & $* *$ & 0.28 & $* *$ & 0.27 & $* *$ & -0.01 & 1 \\
\hline Means & 4.21 & & 1.81 & & 2.00 & & 3.91 & & 2.72 & & 3.41 & 8.06 \\
\hline S.D. & 5.76 & & 0.69 & & 1.12 & & 1.81 & & 1.45 & & 1.15 & 2.24 \\
\hline
\end{tabular}

\subsection{Model Evaluation and Revision}

The first phase structural equation modeling analysis result, for the assessment of the stability of our proposed model, (refer to fit indices in Table 2) suggested a suboptimal fit between the proposed 
model and data (calibration sub-sample). However, most proposed model paths (relationships) emerged as positive and significant as we theoretically conjectured. The path between shareholder meetings and shared identify failed to achieve significance. Further, the modification indices indicated the possibility of a direct relationship between family TMT and TI, which we accepted for phase two and phase three of the study. Also, we accepted the multiple competing model analysis during the first phase, which consisted of reversing one path (relationship direction), one at a time, between study variables in the first proposed model and comparing resulting fit (of the model with data) with the fit of the original model. The results suggested that each of the competing models with a reserved path resulted in a deteriorating fit between the altered model and data compared to the original proposed model. This ruled out the possibility of reserve directionality in the relationship among the study variables.

Table 2. Standardized path estimates for the initial model and the revised model.

\begin{tabular}{|c|c|c|c|c|c|c|}
\hline \multirow[b]{2}{*}{ Paths } & \multicolumn{2}{|c|}{$\begin{array}{l}\text { Calibration Sub-Sample } \\
\text { Initial Model }(n=945)\end{array}$} & \multicolumn{2}{|c|}{$\begin{array}{l}\text { Calibration Sub-Sample } \\
\text { Revised Model }(\mathrm{n}=945)\end{array}$} & \multicolumn{2}{|c|}{$\begin{array}{l}\text { Validation Sub-Sample } \\
\text { Revised Model }(\mathrm{n}=945)\end{array}$} \\
\hline & Path Estimate & $T$-Value & Path Estimate & $T$-Value & Path Estimate & $T$-Value \\
\hline Ownership $\rightarrow$ Shared Identity & 0.12 & 2.64 & 0.12 & 2.71 & 0.02 & 0.41 \\
\hline Shareholder Meeting $\rightarrow$ Shared Identity & 0.03 & 0.63 & 0.03 & 0.63 & -0.01 & -0.23 \\
\hline Investment Percent $\rightarrow$ Shared Identity & 0.12 & 3.34 & 0.12 & 3.34 & 0.08 & 2.03 \\
\hline $\mathrm{R}^{2}$ (Social Identity) & \multicolumn{2}{|l|}{0.08} & \multicolumn{2}{|l|}{0.08} & \multicolumn{2}{|l|}{0.07} \\
\hline \multicolumn{7}{|l|}{ TI } \\
\hline Ownership $\rightarrow$ TI & 0.07 & 1.62 & 0.02 & 0.58 & 0.05 & 1.36 \\
\hline Shared Identity $\rightarrow$ TI & 0.30 & 8.02 & 0.27 & 7.06 & 0.27 & 7.18 \\
\hline
\end{tabular}

Note: $t$-value $\geq 1.96$ indicates significance at the 0.05 level; $t$-value $\geq 1.65$ indicates significance at the 0.10 level.

In the phase two analysis, we revised the proposed model by adding the suggested path (family $\mathrm{TMT} \rightarrow \mathrm{TI}$ ) from the phase one results. We retested the revised model on the calibration sub-sample used in the first phase. The result (refer to the fit indices in Table 2) indicated that the revised model had a good fit with the data. There was no change in the significance level of the paths between the study variables that we reported previously. The revised model, with a path from family TMT $\rightarrow$ TI, was further validated on the remaining sub-sample of family firms with CEOs related to the family by blood/adoption (validation sub-sample). The results (refer to the fit indices in Table 2) indicated that the revised model had a good fit with the validation sub-sample. To assess the mediating effect of shared identity, we analyzed the indirect influence of family influence on TI, which we report in Table 3.

Table 3. Standardized indirect path estimates for TI.

\begin{tabular}{ccccc}
\hline & \multicolumn{2}{c}{$\begin{array}{c}\text { Calibration Sub-Sample } \\
\text { Revised Model }(\mathbf{n}=\mathbf{9 4 5})\end{array}$} & \multicolumn{2}{c}{$\begin{array}{c}\text { Validation Sub-Sample } \\
\text { Revised Model (n = 945) }\end{array}$} \\
\hline Indirect Paths & Path Estimate & T-Value & Path Estimate & $\boldsymbol{T}$-Value \\
\hline Shareholder Meeting $\rightarrow$ TI & 0.01 & 0.63 & 0.00 & -0.23 \\
Family Meeting $\rightarrow$ TI & 0.04 & 2.93 & 0.05 & 3.60 \\
Family TMT $\rightarrow$ TI & 0.03 & 2.61 & 0.04 & 3.33 \\
Investment Percent $\rightarrow$ TI & 0.03 & 3.02 & 0.02 & 1.96 \\
\hline
\end{tabular}


We used the revised model to conduct measurement invariance analysis among the three sub-samples of family firms based on the CEO type (RB, RM, and NF) to assess the moderating influence of $\mathrm{CEO}$ type. For the measurement invariance, our benchmark level of invariance included the most constrained criteria, where all revised model parameters were forced to be equal among the three sub-samples (CEO type had no influence on the model, thus there was no moderating influence of CEO type). The result of the simultaneous three group analysis for the benchmark invariance, the chi-square statistic $\left(\chi^{2}{ }_{29}=49.62, p<0.05\right)$ along with $<3$, suggested an adequate level of fit [59]. Later, using a nested model testing approach, we allowed only one path in one sub-sample (out of the three included sub-samples) to vary as compared to the benchmark model. We then examined the resulting improvement or deterioration in the model fit using the resulting $\chi^{2}$ change. When the $\chi^{2}$ change was significant, we concluded that the CEO type moderates the relationship between the variables, whose paths were allowed to vary. We exhaustively repeated this test for all hypothesized paths in our model. Results of the measurement invariance for the benchmark are shown in Table 4, while the results for the less constrained models (for assessing moderation) are shown in Table 5.

Table 4. Standardized path estimates and fit statistics three-group measurement invariance.

\begin{tabular}{|c|c|c|}
\hline & \multicolumn{2}{|c|}{ Base Model } \\
\hline Paths & Path Estimates & $T$-Value \\
\hline \multicolumn{3}{|l|}{ Shared Identity } \\
\hline Ownership $\rightarrow$ Shared Identity & 0.03 & 1.50 \\
\hline Shareholder Meeting $\rightarrow$ Shared Identity & 0.01 & 0.65 \\
\hline Family Meeting $\rightarrow$ Shared Identity & 0.14 & 6.47 \\
\hline Family TMT $\rightarrow$ Shared Identity & 0.12 & 5.58 \\
\hline Investment Percent $\rightarrow$ Shared Identity & 0.09 & 4.21 \\
\hline $\mathrm{R}^{2}$ (Shared Identity) & \multicolumn{2}{|c|}{0.06} \\
\hline \multicolumn{3}{|l|}{ TI } \\
\hline Ownership $\rightarrow$ TI & 0.05 & 2.41 \\
\hline Shared Identity $\rightarrow \mathrm{TI}$ & 0.24 & 11.70 \\
\hline Family TMT $\rightarrow$ TI & 0.21 & 10.19 \\
\hline $\mathrm{R}^{2}(\mathrm{TI})$ & \multicolumn{2}{|c|}{0.16} \\
\hline Fit-Statistics & \multicolumn{2}{|c|}{$\begin{array}{c}\chi^{2}{ }_{29}=49.62, p<0.05 ; \mathrm{RMSEA}=0.035 ; \mathrm{RMR}=0.08 \\
\mathrm{NFI}=0.94 ; \mathrm{NNFI}=0.94 ; \mathrm{CFI}=0.97 ; \mathrm{GFI}=0.97\end{array}$} \\
\hline
\end{tabular}

Table 5. Test for moderation effect across three groups (RB: Related by birth or adoption, RM: Related by marriage, and NF: Not related).

\begin{tabular}{ccc}
\hline Path Free Across Three Groups & $\begin{array}{c}\chi^{2} \text { Difference: Baseline vs. } \\
\text { Less Constrained Model }\end{array}$ & $\begin{array}{c}\chi^{2} \text { Difference Test } \\
\text { Conclusion }\end{array}$ \\
\hline Ownership $\rightarrow$ Shared Identity & $\chi^{2}{ }_{1}=0.99-1.42$ & $\mathrm{RB}=\mathrm{RM}=\mathrm{NR}$ \\
Shareholder Meeting $\rightarrow$ Shared Identity & $\chi^{2}{ }_{1}=0-0.02$ & $\mathrm{RB}=\mathrm{RM}=\mathrm{NR}$ \\
Family Meeting $\rightarrow$ Shared Identity & $\chi^{2}{ }_{1}=0-2.73$ & $\mathrm{RB}=\mathrm{RM}=\mathrm{NR}$ \\
Family TMT $\rightarrow$ Shared Identity & $\chi^{2}{ }_{1}=0.04-0.47$ & $\mathrm{RB}=\mathrm{RM}=\mathrm{NR}$ \\
Investment Percent $\rightarrow$ Shared Identity & $\chi^{2}{ }_{1}=0.01-0.04$ & $\mathrm{RB}=\mathrm{RM}=\mathrm{NR}$ \\
Shared Identity $\rightarrow$ TI & $\chi^{2}{ }_{1}=3.32-6.01 * *$ & $\mathrm{RM} \neq \mathrm{RB}=\mathrm{NR}$ \\
Family TMT $\rightarrow$ TI & $\chi^{2}{ }_{1}=0-0.32$ & $\mathrm{RB}=\mathrm{RM}=\mathrm{NR}$ \\
\hline
\end{tabular}

${ }^{*}$ Range of chi-square difference. ${ }^{* *} \chi^{2}$ was significant for just $\mathrm{RM} \neq \mathrm{RB}=\mathrm{NR}$ case.

\subsection{Hypothesis Testing}

For the first hypothesis, we were expecting the four family influence indicators (shareholder meeting, family meeting, family TMT, and investment percent) to positively influence the shared identity. As can be observed in Tables 2 and 4, all family influence variables, with the exception of shareholder meeting, had a significant and positive influence on shared identity. Only shareholder 
meeting failed to achieve a significant influence on shared identity. In general, though, the results provided support for hypothesis $\mathrm{H} 1$.

The second hypothesis $(\mathrm{H} 2)$ suggested a positive relationship between the family's shared identity and the TI. Again, as shown in Tables 2 and 4, shared identity influence on the TI was positive and significant. Thus, we conclude that hypothesis $\mathrm{H} 2$ is supported.

In hypothesis H3, we proposed shared identity as the mediator between family influence and the TI. As shown in Table 3, TI had a significant indirect influence from the family influence variables, with the exception of shareholder meeting. Thus, hypothesis H3 is supported.

$\mathrm{H} 4$ proposed that the CEO type, based on their connection to the family (by marriage vs. through marriage vs. through hire), would moderate the relationship between shared identity and the TI. As can be seen in Table 5, the CEO type influences the relationship between shared identity and TI as predicted. Thus, $\mathrm{H} 4$ is supported.

\section{Discussion and Conclusion}

Different theories of the family firm have proposed that the TI and family influence over the family firm represent some of the defining characteristics of a family business $[1,32,37]$. In this paper, we sought to clarify the relationship between the TI and family influence over the family firm by introducing a new concept of sharing. We hypothesized that shared identity would be positively related to a family's influence over the family firm and the TI; furthermore, we hypothesized that shared identity would mediate the relationship between these two. In addition, we conjectured that a CEO's connection to the family—through marriage, hire, or by blood—would moderate the relationship between the family's business identity and the TI.

Our study findings established that: (1) Family influence was positively related to shared identity; (2) shared identity was positively associated with the TI; (3) shared identity mediated the relationship between family influence over the family firm and the TI; and (4) the type of CEO connection to the family moderated the relationship between the shared identity and the TI either positively (connectedness by blood or through hire) or negatively (relatedness through marriage) as it was hypothesized in the study.

Why are these findings important and what are their practical implications? First, establishing that family influence is positively related to shared identity is important because it helps us understand that family influence may represent a positive factor. This suggests that the family's influence should not be reduced to a manifestation of nepotism, parochialism, and selfish self-centeredness, but rather approached in a more balanced fashion $[11,60,61]$. Furthermore, our findings suggest that when family influence over the family firm is closely related to the family's business identity, such influence is likely to be positive due to the development of psychological ownership in the family. One can expect that the family is genuinely concerned about the family firm and will use its experience and expertise to guide the family business into the future.

In addition, this study enhances our understanding of the constituents of family influence. In the study, we measured family influence through the frequency of family and shareholder meetings, family representation in the firm TMT, and the family investment percent in the firm. Importantly, we were able to show that each of these components of family influence, with the exception of shareholder meetings, was positively related to the family's business identity. The fact that the number of shareholder meetings, contrary to our expectations, was not associated with the family's business identity could be due to a high probability of overlap between family meetings and shareholder meetings. In family firms, there is no distinction between the family and shareholders. Further, the three family influence components had a varying level of influence on the family's business identity, as one would expect. However, the emergence of family meetings as a critical factor in shaping shared identity is noteworthy.

The findings of the study regarding the mediating effects of the family's shared identity also deserve attention. It shows that the family's shared identity can facilitate the relationship between the 
family's influence over the family firm and the TI as a greater business identity may help the family focus on retaining its control over the family firm. Finally, our finding that the CEO's connection to the family through marriage serves as a negative moderator of the relationship between shared identity and the TI helps shed more light on the complexity of the identification processes in organizations [40].

Family members clearly need to believe that the succession process in the family firms is fair and protected from various kinds of manipulation and abuse. If such a belief is undermined by the ability of some unscrupulous individuals to seize control of the family firm in a way that could be regarded by family members as unethical, the will of the family to maintain control of the family firm going into the future could become weaker. Conversely, strong leadership of the family firm that could stem from outstanding talent, even in the absence of family relatedness, and family embeddedness could equally boost the family's willingness to continually influence the family firm as well as retain it for the family.

\subsection{Study's Limitations}

We would like to acknowledge certain limitations of our study. First, the sample we used was cross-sectional and data was reported by individual respondents representing the entire family. Casting a wider net by contacting numerous members of the family could provide a richer picture and enhance our understanding of the key concepts. Also, establishing causality in cross sectional data is hard even though we tested alternative models to rule out reverse causality in the study. Another limitation was that we used existing surveys and did not have much control over the variables. Verifying the ideas developed in this study by conducting a survey specifically developed for the examination of the question of families' business identities could enhance the validity of the study. Finally, our sample was limited to businesses operating in the U.S. Collecting a sample of family firms operating in various international locations could certainly enhance the generalizability of our findings.

\subsection{Future Directions}

In the future, the results of the study should be tested with a specifically developed research design across various cultural contexts. Longitudinal and qualitative research could also add more depth to our suppositions and demonstrate how a family's business identity is actually generated in the process of family discussions and potentially even clashes between different family members. Another important direction is to examine the heterogeneity of family firms in terms of their social orientation or social identity.

Author Contributions: This article was a collaborative effort of the authors under the supervision of R.V.M. Both R.V.M. and J.-S.C. developed and ran the initial data analysis, and the paper was fully developed with the contributions of S.A. and W.C.M. The final writing of the paper was accomplished through the iterative efforts of all of the authors.

Funding: This research received no external funding.

Conflicts of Interest: The authors declare no conflict of interest.

\section{References}

1. Chua, J.H.; Chrisman, J.J.; Sharma, P. Defining the family business by behavior. Entrep. Theory Pract. 1999, 23, 19-39. [CrossRef]

2. Casson, M. The economics of the family firm. Scand. Econ. Hist. Rev. 1999, 47, 10-23. [CrossRef]

3. Ward, J.L. Perpetuating the family business. In Family Business Sourcebook; Aronoff, C.E., Ward, J.L., Eds.; Omnigraphics, Inc.: Detroit, MI, USA, 1991.

4. Mahto, R.V.; Ahluwalia, S.; Khanin, D. Psychological ownership of family firm successors: A conceptual approach. Small Bus. Inst. J. 2014, 10, 65-76.

5. Mahto, R.V.; Davis, P.S.; Khanin, D. Continuation commitment: Family's commitment to continue the family business. J. Fam. Econ. Issues 2014, 35, 278-289. [CrossRef]

6. Stewart, A.; Hitt, M.A. Why can't a family business be more like a nonfamily business? Modes of professionalization in family firms. Fam. Bus. Rev. 2012, 25, 58-86. [CrossRef] 
7. Zellweger, T.M.; Nason, R.S.; Nordqvist, M.; Brush, C.G. Why do family firms strive for nonfinancial goals? An organizational identity perspective. Entrep. Theory Pract. 2011, 37, 229-248. [CrossRef]

8. Zellweger, T.M.; Kellermanns, F.W.; Chrisman, J.J.; Chua, J.H. Family control and family firm valuation by family CEOs: The importance of intentions for transgenerational control. Org. Sci. 2012, 23, 851-868. [CrossRef]

9. Berrone, P.; Cruz, C.; Gomez-Mejia, L.R. Socioemotional wealth in family firms: Theoretical dimensions, assessment approaches, and agenda for future research. Fam. Bus. Rev. 2012, 25, 258-279. [CrossRef]

10. Sharma, P.; Chrisman, J.J.; Chua, J.H. Predictors of satisfaction with the succession process in family firms. J. Bus. Vent. 2003, 18, 667-687. [CrossRef]

11. Miller, D.; Le Breton-Miller, I.; Lester, R.H. Family and lone founder ownership and strategic behaviour: Social context, identity, and institutional logics. J. Manag. Stud. 2011, 48, 1-25. [CrossRef]

12. Ward, J.L. Keeping the Family Business Healthy: How to Plan for Continuing Growth, Profitability, and Family Leadership; Jossey-Bass: San Francisco, CA, USA, 1987.

13. Calabrò, A.; Minichilli, A.; Amore, M.D.; Brogi, M. The courage to choose! Primogeniture and leadership succession in family firms. Strateg. Manag. J. 2018, 39, 2014-2035. [CrossRef]

14. Sharma, P.; Chrisman, J.J.; Chua, J.H. Succession planning as planned behavior: Some empirical results. Fam. Bus. Rev. 2003, 36, 1-15. [CrossRef]

15. Sharma, P.; Irving, P.G. Four bases of family business successor commitment: Antecedents and consequences. Entrep. Theory Pract. 2005, 29, 13-33. [CrossRef]

16. Chang, S.; Shim, J. When does transitioning from family to professional management improve firm performance? Strateg. Manag. J. 2015, 36, 1297-1316. [CrossRef]

17. McMullen, J.S.; Warnick, B.J. To nurture or groom? The parent-founder succession dilemma. Entrep. Theory Pract. 2015, 39, 1379-1412. [CrossRef]

18. Ajzen, L. From Intentions to Actions: A Theory of Planned Behavior. In Action Control: From Cognition to Behavio; Springer: New York, NY, USA, 1985.

19. Williams, D.W.; Zorn, M.L.; Crook, T.R.; Combs, J.G. Passing the torch: Factors influencing transgenerational intent in family firms. Fam. Relat. 2013, 62, 415-428. [CrossRef]

20. Pierce, J.L.; Kostova, T.; Dirks, K.T. Toward a theory of psychological ownership in organizations. Acad. Manag. Rev. 2001, 26, 298-310. [CrossRef]

21. Sharma, P.; Rao, A.S. Successor attributes in Indian and Canadian family firms: A comparative study. Fam. Bus. Rev. 2000, 13, 313-330. [CrossRef]

22. Tajfel, H. Social categorization, social identity and social comparison. In Differentiation between Social Groups: Studies in the Social Psychology of Intergroup Relations; Tajfel, H., Ed.; Academic Press: London, UK, 1978; pp. 77-98.

23. Tajfel, H. Social psychology of intergroup relations. Ann. Rev. Psychol. 1982, 33, 1-39. [CrossRef]

24. Ashforth, B.E.; Mael, F. Social identity and the organization. Acad. Manag. Rev. 1989, 14, 20-39. [CrossRef]

25. Gioia, D.A.; Price, K.N.; Hamilton, A.L.; Thomas, J.B. Forging an identity: An insider-outsider study of processes involved in the formation of organizational identity. Adm. Sci. Q. 2010, 55, 1-46. [CrossRef]

26. Whetten, D.A.; Mackey, A. A social actor conception of organizational identity and its implications for the study of organizational reputation. Bus. Soc. 2002, 41, 393-414. [CrossRef]

27. Corley, K.G.; Harquail, C.V.; Pratt, M.G.; Glynn, M.A.; Fiol, C.M.; Hatch, M.J. Guiding organizational identity through aged adolescence. J. Manag. Inq. 2006, 15, 85-99. [CrossRef]

28. Whetten, D.A. Albert and Whetten revisited: Strengthening the concept of organizational identity. J. Manag. Inq. 2006, 15, 219-234. [CrossRef]

29. Dutton, J.E.; Dukerich, J.M.; Harquail, C.V. Organizational images and member identification. Adm. Sci. Q. 1994, 39, 239-263. [CrossRef]

30. Ditmar, H. The Social Psychology of Material Possessions: To Have Is to Be; St Martin Press: New York, NY, USA, 1992.

31. Pierce, J.L.; Van Dyne, L.; Cummings, L. Psychological ownership: A conceptual and operational exploration. South. Manag. Assoc. Proc. 1992, 203, 211.

32. Chrisman, J.J.; Chua, J.H.; Pearson, A.W.; Barnett, T. Family involvement, family influence, and family-centered noneconomic goals in small firms. Entrep. Theory Pract. 2010, 36, 267-293. [CrossRef] 
33. Anderson, R.C.; Reeb, D.M. Board composition: Balancing family influence in S\&P 500 firms. Adm. Sci. Q. 2004, 49, 209-237.

34. Chrisman, J.J.; Chua, J.H.; Sharma, P. Trends and directions in the development of a strategic management theory of the family firm. Entrep. Theory Pract. 2005, 29, 555-575. [CrossRef]

35. Shanker, M.; Astrachan, J. Myths and realities: Family businesses' contributions to the u.s. economy-a framework for assessing family business statistics. Fam. Bus. Rev. 1996, 9, 107-123. [CrossRef]

36. Gonzalez, A.; Rodriguez, Y.; Sossa, A. Leadership and governance decisions in family business performance: An application of fuzzy sets logic. J. Small Bus. Strat. 2017, 27, 51-66.

37. Astrachan, J.H.; Klein, S.; Smyrnios, K. The F-PEC scale of family influence: A proposal for solving the family business definition problem. Fam. Bus. Rev. 2002, 15, 45-57. [CrossRef]

38. Astrachan, J.H.; Jaskiewicz, P. Emotional returns and emotional costs in privately-held family businesses: Advancing traditional business valuation. Fam. Bus. Rev. 2008, 21, 139-149. [CrossRef]

39. Zellweger, T.M.; Astrachan, J.H. On the emotional value of owning a firm. Fam. Bus. Rev. 2008, 21, 347-363. [CrossRef]

40. Dutton, J.E.; Roberts, L.M.; Bednar, J. Pathways for positive identity construction at work: Four types of positive identity and the building of social resources. Acad. Manag. Rev. 2010, 35, 265-293.

41. Hambrick, D.C.; Mason, P.A. Upper echelons: The organization as a reflection of its top managers. Acad. Manag. Rev. 1984, 9, 193-206. [CrossRef]

42. Norburn, D. The chief executive: A breed apart. Strat. Manag. J. 1989, 10, 1-15. [CrossRef]

43. Avey, J.B.; Avolio, B.J.; Crossley, C.D.; Luthans, F. Psychological ownership: Theoretical extensions, measurement, and relation to work outcomes. J. Org. Behav. 2009, 30, 173-191. [CrossRef]

44. Khanin, D.; Turel, O.; Mahto, R.V. How to increase job satisfaction and reduce turnover intentions in the family firm: The family-business embeddedness perspective. Fam. Bus. Rev. 2012, 25, 391-408. [CrossRef]

45. Anderson, R.C.; Reeb, D.M. Founding-family ownership and firm performance: Evidence from the S\&P 500. J. Financ. 2003, 58, 1301-1328.

46. Morck, R.; Yeung, B. Agency problems in large family business groups. Entrep. Theory Pract. 2003, 27, 367-382. [CrossRef]

47. Anderson, R.C.; Reeb, D.M. Founding-family ownership, corporate diversification, and firm leverage. J. Law Econ. 2003, 46, 653-680. [CrossRef]

48. Shleifer, A.; Vishny, R. A survey of corporate governance. J. Financ. 1997, 52, 737-783. [CrossRef]

49. Fahed-Sreih, J.; Djoundourian, S. Determinants of longevity and success in Lebanese family businesses: An exploratory study. Fam. Bus. Rev. 2006, 19, 225-234. [CrossRef]

50. Mehrotra, V.; Morck, R.; Shim, J.; Wiwattanakantang, Y. Must love kill the family firm? some exploratory evidence. Entrep. Theory Pract. 2011, 35, 1121-1148. [CrossRef]

51. Fiegener, M.K.; Brown, B.M.; Prince, R.A.; File, K.M. A comparison of successor development in family and nonfamily businesses. Fam. Bus. Rev. 1994, 7, 313-329. [CrossRef]

52. Joreskog, K.G.; Sorbom, D. LISREL 8: Structural Equation Modeling with SIMPLIS Command Language; Scientific Software International: Hillsdale, NJ, USA, 1993.

53. Allen, D.G.; Mahto, R.V.; Otondo, R.F. Web-based recruitment: Effects of information, organizational brand, and attitudes toward a Web site on applicant attraction. J. Appl. Psychol. 2007, 92, 1696-1708. [CrossRef]

54. Bollen, K.A. A comment on model evaluation and modification. Multivar. Behav. Res. 1990, 25, $181-185$. [CrossRef]

55. Donavan, D.T.; Brown, T.J.; Mowen, J.C. Internal benefits of service-worker customer orientation: Job satisfaction, commitment, and organizational citizenship behavior. J. Mark. 2004, 68, 128-146. [CrossRef]

56. Bentler, R.M.; Bonett, D.G. Significance tests and goodness of fit in the analysis of covariance structures. Psychol. Bull. 1980, 88, 588-606. [CrossRef]

57. Hu, L.; Bentler, P.M. Cutoff criteria for fit indexes in covariance structure analysis: Conventional criteria versus new alternatives. Struct. Equ. Model. 1999, 6, 1-55. [CrossRef]

58. Joreskog, K.G.; Sorbom, D. LISREL VI User's Guide; Scientific Software: Mooresville, IL, USA, 1984.

59. Hughes, M.A.; Price, R.L.; Marrs, D.W. Linking theory construction and theory testing: Models with multiple indicators of latent variables. Acad. Manag. Rev. 1986, 11, 128-144. [CrossRef] 
60. Bertrand, M.; Schoar, A. The role of family in family firms. J. Econ. Perspect. 2006, 20, 73-96. [CrossRef]

61. Schulze, W.S.; Lubatkin, M.H.; Dino, R.N.; Buchholtz, A.K. Agency relationship in family firms: Theory and evidence. Org. Sci. 2001, 12, 99-116. [CrossRef] 